\title{
Jingshu Zhu
}

Leiden University, The Netherlands

\begin{abstract}
This article explores the controversial kinship practice in mainland China of 'gay' men marrying unwitting women. It questions the 'marriage fraud' discourse that condemns the men involved while pitying their wives, or tongqis. Taking an ethnographic approach, this article considers the major flaws of this popular discourse: the idealized-package of marriage-love-sex, the oft-neglected difficulties of living outside marriage, and most importantly, the essentialization of homosexuality. It also examines the im/possibility for married 'gay' men to be honest in their marriages. Finally, it cautions that honesty, if used as a decontextualized ethical yardstick for queer kinship, may obscure the racist and homophobic prejudices that exist both outside and inside queer communities. Accordingly, this article proposes that we shift to 'opacity' as an epistemological, methodological and ethical parameter that radically queers kinship (studies).
\end{abstract}

\section{Keywords}

Honest, mixed-orientation marriage, opacity, queer kinship, tongqi

\section{Introduction}

In recent years, China, along with other Asian countries, has seen the rise of LGBT rights movements, including growing advocacy for same-sex marriage. There appears to be a trend of 'global queering' (Altman, 1996) where queer ${ }^{1}$ people in China, like their Western pioneers, dare to come out, form families, and ask for socio-legal recognition. However, this narrative of multicultural liberal progression may not do justice to the intricate entanglements of queer Chinese with their specific social-familial environment.

\section{Corresponding author:}

Jingshu Zhu, Leiden University Boerhaavelaan 268, 2334EZ Leiden, The Netherlands.

Email: zjs.jess@gmail.com 
Although queers in the global West also live in a largely heteronormative society, the pressure to get married and have children is extraordinarily pronounced in China, especially for the single-child generation born after the 1980s. Despite the so-called Chinese 'sex revolution' (Pan and Huang, 2011) over the last three decades that have gradually decoupled sex from marriage and procreation, reproductive marriage still functions to promote sexual normalcy, social advantages and the hope of greater security in later life (Fincher, 2014).

For Chinese queers who feel unable, robustly or tacitly, to refuse marriage, two main coping strategies against the marital pressure present themselves. One is the openly negotiated 'fake' marriage, or cooperative marriage, between a lesbian and a gay man; the other is to conceal their same-sex attraction and marry an unsuspecting person of the different sex. Notwithstanding some debates within queer communities (Wang, 2015: 99-124), scholars tend to valorize cooperative marriage as a 'silent force of resistance' (Kam, 2013: 100), a 'new intimate alliance' (Wang, 2015) or a 'queer kinship practice' (Engebretsen, 2014: 59) that tacitly subverts the hetero-patriarchal institution of marriage. Indeed, the informed consent, the open relationship, the mutual assistance, the relatively egalitarian distribution of spousal responsibilities, and the non-confrontational infra-politics enshrined in cooperative marriages are all inspiring. However, few queer scholars have examined the more disturbing yet more prevalent phenomenon, namely, the 'marriage fraud' (pian hun).

'Marriage fraud' is used almost exclusively in contemporary China to refer to a scenario where a closeted 'gay' 2 man seeks to pass as heterosexual by marrying a non-complicit woman, hence making her a tongqi (literally, 'a gay man's wife'). The 'tongqi' has become a social phenomenon, yet conversely there is little discussion of heterosexually married lesbians. For that reason, this article will focus on same-sexattracted men and their wives. With the ever-increasing gay visibility, women have started to question whether their indifferent or feminine husbands might be 'gay'. After some wives came forward publicly with tragic stories of their 'fraudulent' marriages, more and more self-identified tongqis have grouped together online and offline to condemn 'gay liars'. One quantitative study concludes that roughly 14 million Chinese 'gay' men (nan tong) have fraudulently married, providing an estimate of the number of tongqis (Liu et al., 2013). Many media reports, often citing such striking statistics, strongly sympathize with tongqis, especially with their lack of sexual satisfaction in marriage, as evidenced by eye-catching headlines such as 'My husband never saw me naked' or 'Still a virgin in her 60s'. The women's unfortunate predicament has provoked considerable public anger, while articles purporting to explain how to tell if a boyfriend or husband is gay have gone viral.

Although mixed-orientation marriages do exist in Anglophone cultures (Hernandez et al., 2011; Ross, 1983), only in mainland China have wives adopted a collective identity with publicly articulated political aims. In addition to calling for societal attention and providing mutual help, some tongqis aim to change the marriage law, putting the homosexual spouse at fault, thereby disadvantaging them in divorce lawsuits over custody and property division. Others have thrown 
themselves into campaigning for same-sex marriage, hoping to give gay men the option to marry their same-sex partners and thus prevent other women from suffering similar misfortunes (see, e.g., Jiang, 2013). Noticing this particularity, this article begins by asking: Why would millions of Chinese same-sex-attracted men prefer to be 'unreal', 'unethical' and 'unqueer' in a different-sex marriage? Why is it only in contemporary mainland China that there is a wounded identity encapsulated in the term tongqi?

These questions might better be answered through the storytelling of those who have been, or still are, living in such marriages. The source material comes from my fieldwork in China in 2014. Introduced by PFLAG China, an organization providing support for lesbians and gays to come out to their family, I got to know a tongqi activist who had frequently participated in PFLAG's story-sharing events. Through her as a gatekeeper, I joined an internet chatroom with 132 tongqi members and conducted online participant observation for 8 months. I also conducted in-depth interviews, either face-to-face or down-the-line, ${ }^{3}$ with 12 self-identified tongqis and 7 married same-sex-attracted men. This article cannot fully cover their life stories, but hopefully the selected narratives can shed light on the hurt feelings of tongqis, while questioning how honesty and closet have together created a double bind for 'gay' men in different-sex marriages. Finally, it reconsiders the ethics of queer kinship through such complexities.

\section{Why 'marriage fraud' hurts}

In everyday life, withholding of information (an inaction) is not widely considered fraud (an action). Only when people legitimately expect to be given certain information can non-disclosure be tantamount to fraud. The key question becomes what 'legitimate expectations' necessitate disclosure (Carson, 2010: 260). Tongqis and their sympathizers seem to see the legitimacy of two 'expectations' as indisputable: that marriage should ideally provide hetero-romantic-sexual love and a stable family life; and, as a minimum, that only heterosexuals should be entering different-sex marriages. The following section will unpack how these expectations work to produce 'gay frauds' and the hurt felt by tongqis.

\section{The ideal package of marriage-love-sex}

The sense of 'legitimate expectation' of a hetero-romantic, 'happily-ever-after' marriage can be found in the stories of many tongqis who joined the chatroom. They had gone through similar phases, from having a 'sweet honeymoon period', 'sensing something suspicious but not knowing what', 'finding out the shocking secret of their husband's "gayness", to 'feeling used and fooled'. Ah-Mei, a 35-year-old businesswoman, expressed her sense of lack after a recent divorce:

Once I asked if he ever loved me. He said yes. Then I asked if it was the kind of love I wanted. He said it was more like familial love ... I acknowledge a little bit of love 
between us, but there was no passion. We were more like siblings. Now I really want to experience the pure, unconditional love.

The valorization of romantic love as a prerequisite of marriage has not been a given in China. Traditionally the primary functions, or the dominant legitimate expectations, of marriage in China have been continuing the blood line and providing old-age security ( $\mathrm{Li}, 1991)$. In fact, until the late Qing Dynasty, male homoerotic practices were not problematized as a pathological inner trait incompatible with marriage and procreation (Martin, 2011). Different-sex courtship and premarital romantic relationships only became important during the modernizing era in the early 20th century (Sang, 2003: 15). Although match-by-introduction and marrying without profound mutual affection are still common practices today, by the end of the 1990s, romantic love has gained increasing cultural importance in spouse selection (Yan, 2003). Men are expected, in addition to being bread-winners and protectors, to provide emotional care for their wives and children in order to be considered a 'good husband' in civilized society (Louie, 2002). These culturally sanctioned criteria give tongqis legitimate reasons for accusing their husbands of failing their spousal duties.

Implicit in tongqis' longing for romantic love within marriage is also the expectation of conjugal sex (Giddens, 1992: 61). Great emphasis has been placed on sexual satisfaction, especially in urban China (Pan and Huang, 2011). With the state's encouragement of individual fulfilment and the popularization of medical-psychological knowledge about sexual dysfunction, sexual pleasure has become a new ethical code for conjugality (Yan, 2003). Marriage without sex is represented as incomplete, pathological, and pathetic in mainstream discourse (Wong, 2015). Meanwhile, bombarded by the dazzling ideals of sexual happiness peddled by commercials, relationship-advice bloggers and the pharmaceutical industry, more and more Chinese women began to talk about and seek out sexual pleasure (Pei, 2007). Such an environment gives self-identified tongqis greater courage to come forward and publicly accuse their 'gay' husbands of avoiding having sex with them (Xing, 2012).

While an increasing number of Chinese people accept pre-marital sex, many women still preserve their virginity as a valued 'gift' for their husbands-to-be (Zheng et al., 2011), which implies a lingering patriarchal norm of female chastity. Ah-Mei, like many other tongqis, entered into marriage three months after meeting her husband, 'without even holding hands'; nor was sexual preference an important criterion for her to choose a partner for life. One should not, however, simply blame tongqis' own 'conservativeness' or 'recklessness' in marrying someone without first checking out their sexual preferences. The shaming of women's sexual desire outside marriage and the excessive importance placed on conjugal sex are two sides of the same knowledge/power coin that traps many tongqis in the idealized package of marriage-love-sex. When the 'marriage fraud' discourse castigates the 'loveless' and 'sexless' mixed-orientation marriages as unworthy and unfortunate, it only obscures the fact that marriage for many, whether straight or gay, used to be, and to a large extent still is, a vehicle for calculation and acquisition of 
economic interests and social decency (Graff, 1999), which had already 'contaminated' the 'purity' of hetero-romantic-sexual love.

In summary, the rise of the marriage-love-sex ideal has made previously 'normal' unromantic, unsexy marriages less and less defensible. However, it would be oversimplifying to attribute tongqis' complaints to their failure to actualize the illusorily high expectations of a loving, sexual marriage. After all, not all tongqis have internalized this ideal, but still find themselves in despair. Other concerns are at play here.

\section{The high price of living without marriage}

For many Chinese people, tongqis included, despite the desirability of the ideal package, romance and sex are usually not prioritized over more pragmatic considerations in making marriage decisions. They know that marriage can be imperfect and sometimes suffocating, but one can hardly afford not having it.

Yan was a 38-year-old high-school teacher in a small city. She endured an unhappy marriage for 10 years, although she had first seen her husband's online chat history in the third year. Besides lamenting her bad luck of having married a 'gay' man, Yan expressed other concerns. She recalled a pragmatic reason that pressured her, like many other women, to rush into marriage: the prevailing notion of an 'appropriate age' to marry and give birth. Such pressure is felt by both sexes in China, yet in particular by unmarried females in their late 20s, who are stigmatized as 'leftover women' (Fincher, 2014). Such single-shaming makes young women give up too much bargaining power before and during marriage. The ticking 'marriage and fertility clock' also left Yan little choice other than to follow the gender and sexual norms of a 'moral' woman:

I never dated before I met him. I also believed I shouldn't see other people once I started seeing him; otherwise it's immoral ... And I thought a good woman had better not divorce... My view on relationship and marriage was so problematic then.

Yan's ruthless analysis of herself as 'problematic' should not stop us from scrutinizing the socio-economic structures that made her so. Her lack of courage to select more carefully or to divorce is not uncommon among tongqis, who know full well that the negative judgment of their families and social circles would be unbearable should they choose a less conventional road. More importantly, underlying her moral concerns about being unmarried or divorced, was her sense of economic insecurity:

I didn't know how to live my life alone if I divorced. I feared that I wouldn't find a better job or grow old with proper care ... So, I told myself, 'you might as well stay'.

Yan's words call on us to consider tongqis' difficulties from a materialist feminist perspective. For many women, not just tongqis, marriage is a safe haven, and 
leaving it is not cost-free. Indeed, being a single or divorced woman can be economically disadvantageous, and even more so in neo-liberal China: the wage discrepancy and glass ceiling (Chi and $\mathrm{Li}, 2008$ ), the restrictive policies on single mothers (Palmer, 2007), the skyrocketing real-estate price (Fincher, 2014), shrinking social welfare, and the state's propaganda that shifts eldercare responsibility to core families (Nie, 2016) all contribute to a less livable future for women outside marriage.

Therefore, tongqis' resentment is understandable: their expectations of a loving heterosexual marriage are unrealized, while divorce is not always a practical way out. However, many wives with heterosexual husbands in China and those with homosexual husbands elsewhere are enduring similarly indifferent or even tormented marriages, but none of them have collectively formed an identity based around victimhood. Hence, the specificity of the tongqi phenomenon needs further inquiry.

\section{The essentialization of a 'gay' husband}

As outlined above, for the heterosexual majority, the unmarked expectation for a 'normal' different-sex marriage is that both spouses should be straight. This expectation makes the non-disclosure of the husband's same-sex attraction actively 'fraudulent'. I often heard in the chatroom, 'even if a gay man treats his wife well, he can only give her affection with a discount.' Tongqis' anger is thus not only about their lack of sexual love in marriage or the high price of being unmarried or divorced, which can happen to any woman, but also about 'gay' men's sheer inability to provide it sincerely. Where did this belief come from?

Let us revisit Yan's story. She chose to stay married for 7 more years after her husband admitted his same-sex attraction. One crucial reason was that she had never thought his little 'proclivity' was the biggest problem. This idea was drastically overturned after she joined a tongqi online chatroom in 2013:

When I got married, I just had a vague idea of homosexuality ... it was a decade later that I learnt the scientific fact that they would never love women. I was so stupid to have treated our problem as an average extra-marital affair and hoped that he would come back to me after an occasional digression like other men do. This was my mistake, a fatal mistake ... Only after I joined the tongqi community did I learn that love and biology are inseparable. This idea was strikingly new to me. (emphases added)

Yan's words show the power of knowledge/discourse that produces homosexual subjects (Foucault, 1978) and collaterally, tongqis. In her case, the 'gay' husband was 'gayed', and she was 'tongqi-ed', to appropriate Butler's (1993: 7-8) words on the interpellation of a girl, neither at the moment he discovered his desire, nor when he was caught flirting with a man online, but when his same-sex attraction was collectively confirmed by other tongqis in the group as a 'scientific fact' about his 'biology', 
an inborn and immutable desire for men, not women. Only then was homosexuality constructed as a 'personage' (Foucault, 1978: 43), not just a behavior. The turning point also makes Yan believe retrospectively that all her husband's questionable acts were evidence of his fraudulence, and all the loving acts just cruel lies.

The constructive power of the 'gay fraud' discourse is also established by the exclusionary boundaries of sexual identities. Some women had joined the chatroom with the suspicion that their husbands might be bisexuals. However, without fully discussing their particular situations, the chatroom organizer kept reminding the newcomers: 'bisexuality does not exist, so any effort to make your gay husband love you is futile.' Some senior members concurred, 'bisexuality is simply a feeble excuse for, or even a direct proof of, a man's gayness and cunningness.'

Tongqis' insistence on the essential traits of homosexuality and their negation of bisexuality is not coincidental. Although scholars and activists in the West have long criticized the 'born-this-way' argument (D'Emilio, 1986; Halley, 1994), it is still the most frequently heard rhetoric in Chinese gay rights activism Although queer theory has been introduced to China and aroused fierce debates around 2012 (Chen, 2014), it remains peripheral, compared with the widely disseminated articles about the genetic evidence of homosexuality and its 'immutability'. If homosexuality is inborn and unchangeable, and if bisexuality does not exist, then withholding one's same-sex attraction is certainly a lie about one's 'true self'. With more LGBTs coming out in public, those same-sex attracted men who did not have a clearly identity when they married now all have a name, even though many do not label themselves as such (Wei, 2007). The increasing gay visibility and the media's sensationalist coverage of gay subcultures also make married, stereotypically 'gaylooking' men more likely to arouse suspicion.

Ironically, the two seemingly antagonistic groups, gay men and tongqis, are in fact symbiotic, created by the same set of knowledge/discourse. More specifically, as exemplified in Yan's story, tongqis' confirmation of their husbands' essential homosexuality crystalizes their pasts into one single storyline of 'that explains everything'. Such a 'eureka' moment is often heard in gay men's stories of selfdiscovery as well (D’Emilio, 1986; Halperin, 2002). Another commonality of the two is their 'epistemic erasure' of bisexuality (Yoshino, 2000), where both groups negate a same-sex attracted man's complicated feelings towards a woman that can well be romantic-sexual love, or exceed the narrowly-defined bounds of love.

Consequently, the essentializing discourses employed by both gay groups and tongqis make being a 'gay fraud' especially shameful, much more so than being a closeted, unmarried gay man. Their marriages are deemed substantially worse than any unfaithful marriages between two heterosexuals, because the former is a 'sham' from the very beginning, whereas a straight male cheater might at least have wholeheartedly loved his wife for a while. ${ }^{4}$ A 'gay' husband's 'dishonesty' also arouses more anger than other forms of non-disclosure in dating and marriage, such as a man's exaggerating his wealth or education, or a woman's scheme for immigration or housing. The latter are considered only 'behaviors', whereas a gay husband is hiding the 'truth' of his 'personality'. 
To recap, tongqis' agony is an epitome of many interwoven socio-economic problems in contemporary China, rather than simply the result of a 'gay' secret. When we single out the 'gay' men's non-disclosure without unraveling the underlying implications of marriage and homosexuality, the condemnation of 'marriage fraud' is inevitably homophobic. Then the challenge is: how can we discuss sexual secrets and ethics in intimate relationships without essentializing homosexuality or idealizing heteronormative marriage?

\title{
The im/possible honesty in 'fraudulent' marriages
}

My fieldwork encounters have provided alternative narratives to the mainstream 'marriage fraud' discourse. My research project shifted the focus from 'what harm the husbands' dishonesty does on tongqis' to "what effects the "marriage fraud" discourse has on both parties'. These stories, to various degrees, de-specularize homosexuality and de-glamorize the marriage-love-sex ideal.

Rou is a Tongqi married for 22 years, whose husband came out to her as gay 7 years ago. Other tongqis in the chat room jokingly called her a 'weirdo (qipa)', because she never complained about her marriage, but was rather content:

\begin{abstract}
Now he's my gay best friend (gay-mi) - we go shopping and Karaoke together, and we even watch gay porn on the sofa. Since I've decided not to divorce, I choose to see the positive sides and appreciate his kindness ... This may be incomplete happiness, but I still take it as happiness ... Sometimes I even encourage my husband to find a samesex partner - he's really like my adult son whom I'm eager to find a match for! [grimacing face emoji]
\end{abstract}

Some tongqis in the group expressed their admiration for Rou and said "this is love, big love'. Rou agreed, although she also acknowledged that she was 'extremely lucky to have such a happy ending'. As one of the core members of the group, she did not simply advise other tongqis to divorce or stay, but patiently helped them to figure out the pros and cons of their respective relationships, while providing her own case as an alternative model for a livable mixed-orientation marriage.

Importantly, Rou's relatively happy story should not be taken as a successful coming-out-in-marriage case, as if only happy and transparent marriages can exonerate 'gay' men from being blamed for marrying initially unwitting straight women. In that case, we fall again into the 'marriage fraud' discourse that condemns the closet and that valorizes honesty as always the best policy before and during marriage. We should instead inquire what made her husband's disclosure and their 'happy ending' possible at all. Some clues can be found from Rou's advice to other tongqis in the chatroom:

Sisters, I suggest you not let your husband's sexual orientation prejudice our judgment on his other aspects. This way you can be more rational and objective, and can lower 
the harm on each other ... Do not assume that homosexuals are abnormal. They're just different ...

Also, we should not just 'painfully endure' the marriage; understanding, forgiving, tolerance and appreciation are all important. Of course, such a good marriage is demanding for both parties. Don't forget, a straight marriage is not always smooth, either.

Apparently, Rou did not demonize her husband's sexuality, and did not overromanticize straight marriages. She used love, friendship and kinship interchangeably to describe their relationship. Her shuffling of terms - 'gay best friend', 'mother and son', 'big love' - and her disinterest in accurately defining or ranking them dissolves the otherwise biggest problem of 'fraud', thus making her husband's coming out acceptable.

I have to admit that Rou's story is hardly representative in this chatroom full of unhappy tongqis. She was aware of it as well, and reminded me not to expand her experience to mixed-orientation marriages in general. However, neither can I extrapolate from the anger and sorrow of the visible tongqis to the millions of women in similar marriages, who do not even know the word 'gay' or 'tongqi'. Therefore, I face a methodological dilemma: the impossibility of sampling the silent. The next interviewee brings this issue forward in a disquieting way.

Born in a northern village, Mingyu got married there when he was 26 . Two years before that, he had had his first same-sex sexual encounter, but did not know anything about 'the circle' by then. After marriage, he stopped having casual sex with men until he became a migrant worker in Hong Kong 10 years later. There, he met a fitness trainer who suggested he make quick money by selling sex to men. Taking advantage of the anonymity the metropolis provides, Mingyu became an MB (short for 'money boy', or male-to-male sex workers in this context) (Rofel, 2010), and occasionally accepted female clients.

Within the 'marriage fraud' discourse, Mingyu's wife would be described as a poor rural tongqi who is kept from the 'triple secrets': her husband is a 'gay' man, an MB, and a cheater in marriage. For Mingyu, however, the roles of a husband, a same-sex attracted man, and a sex worker do not bring him as many struggles as one might think. Unlike some gay man who entered into marriage reluctantly, Mingyu expressed his longing for a stable family, not just as a façade. He did not identify with straight, gay, or bisexual; rather, he emphasized his responsibility as a married man:

It's always clear to me that the purpose of selling sex is to support my family. I call my wife and child every day, and give them a monthly living allowance. Now we've built a new house in the village, and I've bought insurance for my kids in Hong Kong.

With a bashful smile, Mingyu also talked about his relationship with his wife:

I can feel her affection for me. We're no longer young, but she would still say sweet words from time to time. Bearing my wife in mind, I try to be as clean as possible during work. 
Mingyu's compartmentalization of sexuality and the desire for familial stability is not unlike many heterosexual men (Giddens, 1992: 117), especially those rural-tourban migrant workers whose sex life in the cities does not necessarily invalidate their commitment to their wives in their hometown (Dai et al., 2015). His nondisclosure can be a vivid counter-example against the obsession with unambiguous identities, clear expression of sexual desires and in-depth communication between spouses that have become increasingly dominant modes of intimacy both in the Western world since modernity and in China today.

Of course, we cannot take the interviewees' words at face value. Even with me, a researcher who promised to anonymize him, Mingyu did not make himself fully transparent. He sometimes gave contradictory details of his relationship status in different interviews. Multiple stigmas have made it impractical and undesirable for him to be 'honest' and 'ethical', either to his wife or to me. Telling the truth selectively or even camouflaging has become part of his survival skills. Is he still a 'responsible married man'? The answer is probably yes, but only if responsibility is not gauged against his dangerous visibility.

One may legitimately speculate: would his wife still love him if she knew the 'truth'? This also leads to some ethical conundrums about my research method: Is she reduced to a 'non-person' if I interviewed Mingyu alone? Would the case study be more rigorous, if she were presented as a 'speaking subject' with first-person narratives that may falsify some words of Mingyu's? Indeed, it is likely that there would be an enormous power imbalance due to their disparity in gender, location and income, which may result in divergent feelings and life choices. Mingyu's wife may hold back her grudges in order to support her children and migrant-worker husband, like numerous Chinese rural 'left-behind wives' do (Wu and Ye, 2016). Also, she may have fewer opportunities and less moral leeway for extra-marital sex than men have (Pei, 2007), so her emotional and sexual needs might be trivialized in Mingyu's storytelling. Therefore, it seems crucial to interview his wife as well.

Nevertheless, in no way could I make our meeting ethical. How could Mingyu introduce me as a researcher on the topic of 'marriage fraud' to his wife, to whom he is always a good, presumably straight, husband? If he were willing to simply introduce me as his friend, would I be breaking the ethical code of obtaining informed consent from her? Even if I could justify such a covert participant observation, what information could I get, in addition to the daily routines and various feelings an 'ordinary' wife can talk about? Or, should I disclose Mingyu's 'true' identities in order to touch upon his wife's 'true' attitudes about them?

Ultimately, facing his wife, I would end up being trapped in a double bind: withholding the 'truth' and revealing it would both make me unethical. The researcher's dilemma is inevitably intertwined with that of the married 'gay' men: once they are married, hiding or disclosing their desire is 'hurtful' anyway. The academic imperative for me to give voice to the silent subjects overlaps with the political incitements for gay men and tongqis to speak louder about their sexualities and traumas. To see silence as mere oppression, whether in academia or in gay and tongqi movements, plays right into the obsession with confession, 
which is part of the problematic truth regime that produces the accusation of gay fraudulence in the first place (Foucault, 1978: 27).

Two years later, in a casual chat with Mingyu who was still an MB, I asked about his relationship with his wife. He replied shortly, 'very good, as usual'. I could have asked further how he felt about his secrets, but I realized that what buttressed this question was the assumption of a deeper, darker inner truth and the distrust of his shallow, simple words. 'Speaking simply' seems insincere and unacceptable in a 'gay' man's self-description of his presumably struggling marriage, as well as in an academic interview. However, if Roland Barthes (1977: 142) was right that 'speaking simply' is as a nuanced form of silence that breaks the duality of speech/silence, can we draw some implications from these 'incomplete' interviews?

\section{From honesty to opacity: Rethinking the ethics of queer kinship}

The accusation of 'marriage fraud' has divided queer Chinese. As few married 'gay' men willingly come forward to defend themselves; what is overwhelmingly heard is open LGBTs supporting tongqis and denouncing 'gay frauds'. Public revelation has become an important way to produce ethical, responsible gay citizens in their pursuit of respectability. For instance, one leading LGBT group issued a position paper condemning 'marriage-fraud behaviors', 5 and another initiated an online campaign encouraging gay people to take selfies with a hashtag 'I'm gay, and I won't marry a person of the opposite sex' (Wong, 2016). Many LGBT activists are also fervently calling for straight people's support for marriage equality. They argue that same-sex marriage can allow gay people to legally marry their 'true love'; after all, no one would like to see their daughters, sisters or female friends becoming tongqis. The mainstreaming of Chinese gay movements therefore fosters further stratification within the community based on one's 'authenticity' and 'integrity' in front of the public and their families.

However, as shown in the above analysis, the drawbacks of urging honest disclosure of one's sexuality before or during marriage are salient. Firstly, it retrospectively puts the older same-sex attracted men's marriages in ethical crisis, even though they did not know clearly about their sexualities when they got married, let alone having a 'gay' identity. Secondly, 'honesty' implies an insistence on identifying homosexuals, thereby segregating them from different-sex marriage. It simplifies the widely different subjectivities of these 'gay' men (Halperin, 2002), forecloses the possibility of sexual fluidity (Diamond, 2004), and further essentializes the gay/ straight dichotomy. Moreover, an overemphasis on 'honesty' ignores the unbearable pressure on non-heterosexuals to be 'true' in different-sex marriages, thus failing to question the heteronormative prejudices behind the seemingly genderneutral virtues of 'spousal love' and 'communication'. And above all, the zealous pursuit for honesty neglects Sedgwick's (1990: 69) insightful caveat that subjects can be faulted for not disclosing enough rather than disclosing too much about 
their sexuality. Therefore, the unfriendly environment that deters queer people from coming out plus the imperative of telling truths in marriage have together become a double bind imposed on gay men. In Sedgwick's words, disclosure is 'at once compulsory and forbidden' (p. 70).

Although the problematization of mixed-orientation marriage is a highly contextual phenomenon in contemporary China, the above-stated truth regime is not China-specific. Honesty as a truth regime can be found in other cultures as well, which often subtly relates to racism, homophobia and AIDS-phobia. For instance, compulsory disclosure has been institutionalized in Canada, where concealment of HIV-positive status may constitute a crime (Schulman, 2016). Or, compared with the pitying stories of middle-class white married gay men, as exemplified by the film Brokeback Mountain, African American married men 'on the down low' are being subjected to greater shaming of their comparable dishonesties (Glenn and Spieldenner, 2013). The latter also face policing and profiling, especially in the name of HIV/AIDS intervention (Decena, 2008).

The overriding power of the truth regime urges us to rethink our ethical yardsticks when deciding which relationships count as queer kinship and which do not. Surely, if queer means fervently embracing (sexual) stigmas and turning them loudly into reverse discourse, those closeted Chinese men may not be even qualified as queer subjects at all. And true, the mere fact that queer people establish families is not inherently radical, and does not necessarily make a form of kinship 'queer' (Polikoff, 1987). However, we should not quickly dismiss them as not constituting queer kinship, either. If queerness signifies an 'open mesh of possibilities, gaps, overlaps, dissonances, and resonances, lapses and excesses of meaning' (Sedgwick, 1993: 8), then queer kinship should include all forms of combinations of gender, species, number of family members, or ways of procreation and parenting that put the concept of kinship into question. In that sense, the controversy Chinese 'fraudulent marriages' provokes, whether in public, in LGBT communities or in academia, can arguably be a 'que(e)rying' of kinship, especially the ethics thereof, in an uncomfortable way (Foucault, 1997a).

So what if we shelve honesty as a premise for queer kinship, and caution the insidious hetero- and homonormativity in the longing for gay visibility and respectability? Then we need different ways to talk about the non-disclosure of same-sex attraction in mixed-orientation marriages, among other secrets in relation to gay shame. I suggest we forgo the rhetoric of 'marriage fraud' that is ultimately the product of a problematic confessional obsession, and shift the epistemological paradigm from the 'true self' to 'queer opacity' (De Villiers, 2012). While De Villiers articulates this term mainly in his queer reading of three culturally-iconic figures (including Foucault), here I shall further elaborate in the context of contemporary LGBT rights movements in China and beyond.

Firstly, opacity is an ethical necessity for queer people in societies hostile to both gayness and dishonesty. There, the eagerness of the public to know more 'truth' about gay people, especially the married ones, is as oppressive as, if not more than, the direct verbal or physical violence that keeps them in a silent closet. 
The assumed existence of such 'truth' is related to the essentialization of (homo)sexuality. As an optical spectrum that covers the ambiguous in-betweenness, opacity displaces the binaries of gay/straight, closet/coming out, shame/ proud, visible/invisible, and fake/truth that have produced and reinforced the double bind on gay people. It provides a different parameter from authenticity or visibility for us to understanding various forms of camouflage, be it cooperative marriage or mixed-orientation 'fraudulent' marriage, the ethicality of which should be evaluated on a case-by-case basis.

Opacity as a queer tactic in marriage also rescues us from the stifled imagination of different-sex marriage that bundles romantic love with harmonious sex between a man and a woman. Such an ideal makes it impossible for non-heterosexuals to be both loving and 'true' in marriage. The ubiquity of opacity reminds us of the mixed feelings in marriage that are much more complex than hetero-romantic sexual love, and suggests we ascribe value to the care, support and companionship enshrined in various forms of kinship. Moreover, if opacity is not deemed negative, our nonpejorative thinking of mixed-orientation marriage may be expanded to other secrets in the family, such as stigmatized illnesses (Ning, 2007), sex reassignment surgery (Bettcher, 2006) and paternity secrets (Smart, 2009). In these scenarios, where honesty is risky, queer opacity - whether silences, speaking simply, white lies, a don't-ask-don't-tell policy or other tactics - can be employed as a crucial form of family bonding and communicative practice.

Thirdly, as a queer intervention into mainstream transnational LGBT movements, opacity mitigates the stratification within minorities. Often, homosexuality is tolerable only when it is unambiguously identified, wholeheartedly confessed, and most importantly, voluntarily quarantined from straight people's kinship systems. Opacity indicates the inseparability between 'good' and 'bad' queers, as both are tied to the experience of social exclusion (Love, 2007). Instead of shaming the 'frauds', LGBT groups need to re-strategize. 'Giving voice' to the alternative stories of mixed-orientation marriage is not enough because this is still capsulated in the oppressive linkage between honesty, visibility and respectability. Genuinely inclusive and flourishing queer kinship should embrace the unrecognizable, the unspeakable and the underground, and resist the urge to dig them all 'out'.

This line of thinking leads to the methodological implications of queer opacity. Rejecting a homogeneous representation of vulnerable, and hence pitiable victimhood, a queer research project should be open to the 'inconvenience sample' that may redirect our imagination (Duneier, 2011). The challenge of opacity exposes the ambiguous status of one's thoughts and feelings before being 'enlightened' by what purports to be 'scientific' knowledge, as in Yan's interpellation of her husband's and her own identities after joining the chatroom. Also, instead of seeking the 'true' experiences and feelings of the interviewees or their non-speaking partners, as in Mingyu's case, we may do well to investigate into 'our relationships to truth' (Foucault, 1997b: 327), or the obsession with and the im/possibility of it.

Finally, it is hoped that the discussion of 'marriage fraud' and queer opacity in this article contribute to the queer-kinship studies not just by offering a Chinese 
'case', but by questioning how the line between desirable and discreditable queer kinship is drawn, under whose definitional power, and at whose/what cost. It calls for a de-universalized theorization of queer kinship that could better explain and creatively engage with the seemingly not-so-queer practices, especially those in nonwhite and non-Western realities. After all, we do not want queer kinship to become yet another convenient umbrella term like LGBTIQA ... that condenses and castrates the subjectivities of queer people globally. Kinship can be queered, only when we embrace lived, contradictory and sometimes unsettling diversities.

\section{Acknowledgements}

I would like to thank Professor Josephine Chuen-Juei Ho, Dr Nicholas de Villiers, Dr Xiaofei Guo and Tingting Liu for their inspiration and comments. Thanks also go to my supervisors Professor Saskia Wieirnga and Professor Kees Waadlijk.

\section{Funding}

My PhD was funded by the China Scholarship Council, and there is no conflict of interest.

\section{Notes}

1. As a noun, 'queer' is used as a shorthand for sexual minorities here; the theoretical implications of this word as a verb or an adjective will be discussed throughout this article.

2. I use 'gay' with quotation marks to emphasize the fact that not all the Chinese men who are accused as 'gay frauds' share a gay identity.

3. While online and offline stories are differently situated, we should nevertheless break down the dualism of 'offline as the context and online as the phenomenon' (Orgad, 2005: 64).

4. See, e.g., the Advice section on one of the most influential gay rights organization in China, Aibai, where the advisor Dr Damian Lu insists on the genetics and immutability of homosexuality. Available at: http://www.aibai.cn/advice/ (accessed 23 June 2017).

5. See, e.g., an online discussion, 'Which is more acceptable, your husband is cheating or your husband is gay”? Available at: http://aibai.cn/advice (accessed 23 June 2017).

\section{References}

Altman D (1996) On global queering. Australian Humanities Review 2(2): 1-8.

Barthes R (1977) Roland Barthes by Roland Barthes. New York: Farrar, Straus, and Giroux.

Bettcher TM (2006) Appearance, reality and gender deception: Reflections on transphobic violence and the politics of pretence. In: Murchadha FÓ (ed.) Violence, Victims, Justifications: Philosophical Approaches. Bern: Peter Lang, pp. 175-200.

Butler J (1993) Bodies that Matter: On the Discursive Limits of 'Sex'. New York: Routledge. Carson TL (2010) Lying and Deception: Theory and Practice. Oxford: Oxford University Press.

Chen Y (2014) Everyone is Sailor Moon: The full story of the debate between tongzhi and queer lalas. Queer Lala Times. Available at: https://site.douban.com/211878/widget/ notes/16096623/note/341835795/ (accessed 12 May 2017). 
Chi W and Li B (2008) Glass ceiling or sticky floor? Examining the gender earnings differential across the earnings distribution in urban China, 1987-2004. Journal of Comparative Economics 36(2): 243-263.

D'Emilio J (1986) Making and unmaking minorities: The tensions between gay politics and history. NYU Review of Law and Social Change 1136(1971): 915-922.

Dai W, et al. (2015) Sexual behavior of migrant workers in Shanghai, China. BMC Public Health 15: 1067-1075.

De Villiers N (2012) Opacity and the Closet: Queer Tactics in Foucault, Barthes, and Warhol. Minneapolis: University of Minnesota Press.

Decena CU (2008) Profiles, compulsory disclosure and ethical sexual citizenship in the contemporary USA. Sexualities 11(4): 397-413.

Diamond LM (2004) Sexual Fluidity: Understanding Women's Love and Desire. Cambridge, MA: Harvard University Press.

Duneier M (2011) How not to lie with ethnography. Sociological Methodology 41(1): 1-11.

Engebretsen EL (2014) Queer Women in Urban China: An Ethnography. New York: Routledge.

Fincher LH (2014) Leftover Women: The Resurgence of Gender Inequality in China. London: Zed Books.

Foucault M (1978) The History of Sexuality, Vol. 1: An Introduction. New York: Pantheon Books.

Foucault M (1997a) For an ethics of discomfort. In: Lotringer S and Hochroth L (eds) The Politics of Truth. New York: Seminotext(e), pp. 135-146.

Foucault M (1997b) The masked philosopher. In: Rabinow P (ed.) Ethics: Subjectivity and Truth. New York: The New Press, pp. 321-328.

Giddens A (1992) The Transformation of Intimacy: Sexuality, Love and Eroticism in Modern Societies. Stanford, CA: Stanford University Press.

Glenn CL and Spieldenner AR (2013) An intersectional analysis of television narratives of African American women with African American men on 'the down low'. Sexuality and Culture 17(3): 401-416.

Graff EJ (1999) What Is Marriage For? Boston, MA: Beacon Press.

Halley JE (1994) Sexual orientation and the politics of the biology: A critique of the argument from immutability. Stanford Law Review 46(3): 503-568.

Halperin DM (2002) Homosexuality's closet. Michigan Quarterly Review 41(1): 21-55.

Hernandez BC, Schwenke NJ and Wilson CM (2011) Spouses in mixed-orientation marriage: A 20-year review of empirical studies. Journal of Marital and Family Therapy 37(3): $307-318$.

Jiang C (2013) China's gays and lesbians join the global debate on same-sex marriage. Time. Available at: http://world.time.com/2013/05/01/chinas-gays-and-lesbians-stymied-bylack-of-marriage-equality/ (accessed 12 May 2017).

Kam YLL (2013) Shanghai Lalas: Female Tongzhi Communities and Politics in Urban China. Hong Kong: Hong Kong University Press.

Li Y (1991) Sexuality and Marriage in China. Zhengzhou: Henan People's Press.

Liu M, et al. (2013) Estimation on the numbers of Chinese homosexuality and people with same-sex sexual behaviors and related female groups. Journal of Chemical Information and Modeling 53: 117-121.

Louie K (2002) Theorising Chinese Masculinity: Society and Gender in China. Cambridge: Cambridge University Press. 
Love H (2007) Feeling Backward: Loss and the Politics of Queer History. Cambridge, MA: Harvard University Press.

Martin F (2011) Utopian yearning: Reconstructing China's queer cultural histories. InterAsia Cultural Studies 12(1): 132-138.

Nie J-B (2016) Erosion of eldercare in China: A socio-ethical inquiry in aging, elderly suicide and the government's responsibilities in the context of the one-child policy. Ageing International 41(4): 350-365.

Ning Y (2007) AIDS \& SARS: The ethics of disclosure. In: Sexual Ethics without Morality: Essays on Sexual Ethics and Sex Critique. Jungli: Center for the Study of Sexualities, pp. $159-175$.

Orgad S (2005) From online to offline and back: Moving from online to offline relationships with research informants. In: Christine H (ed.) Virtual Methods: Issues in Social Research on the Internet. Oxford: Berg, pp. 51-65.

Palmer M (2007) Transforming family law in post-Deng China: Marriage, divorce and reproduction. China Quarterly 191. Available at: http://www.journals.cambridge.org/ abstract_S0305741007001658 (accessed 30 August 2013).

Pan S and Huang Y (2011) The rise of rights and pleasure: Towards a diversity of sexuality and gender. In: Zhang K (ed.) Sexual and Reproductive Health in China: Reorienting Concepts and Methodology. Leiden: Brill Academic Publishers, pp. 215-262.

Pei Y (2007) Born in the 70's: Sexuality of young women in contemporary Shanghai. PhD thesis, University of Hong Kong.

Polikoff ND (1987) Lesbians choosing children: The personal is political revisited. In: Pollack S and Vaughn J (eds) Politics of the Heart: A Lesbian Parenting Anthology. Ithaca, NY: Firebrand Books, pp. 48-54.

Rofel L (2010) The traffic in money boys. Positions 18(2): 425-458.

Ross MW (1983) The Married Homosexual Man: A Psychological Study. London: Routledge, Kegan, Paul.

Sang T-ID (2003) The Emerging Lesbian: Female Same-Sex Desire in Modern China. Chicago: University of Chicago Press.

Schulman S (2016) Conflict Is Not Abuse: Overstating Harm, Community Responsibility, and the Duty of Repair. Vancouver: Arsenal Pulp Press.

Sedgwick EK (1990) Epistemology of the Closet. Berkeley: University of California Press.

Sedgwick EK (1993) Tendencies. London: Routledge.

Smart C (2009) Family secrets: Law and understandings of openness in everyday relationships. Journal of Social Policy 38(4): 551-567.

Wang Y (2015) Cooperative marriage: A 'fake marriage' or a new intimate alliance? Master of Philosophy thesis, University of Hong Kong.

Wei W (2007) 'Wandering men' no longer wander around: The production and transformation of local homosexual identities in contemporary Chengdu, China. Inter-Asia Cultural Studies 8(4): 572-588.

Wong D (2015) Asexuality in China's sexual revolution: Asexual marriage as coping strategy. Sexualities 18(1): 100-116.

Wong T (2016) China rights: Gay people pledge not to enter into sham marriages. $B B C$ News, 14 April. Available at: http://www.bbc.com/news/world-asia-china-36042000 (accessed 12 May 2017).

Wu H and Ye J (2016) Hollow lives: Women left behind in rural China. Journal of Agrarian Change 16(1): 50-69. 
Xing F (2012) Report on the Life of Chinese Straight Wives. Chengdu: Chengdu Times Press. Yan Y (2003) Private Life under Socialism: Love, Intimacy and Family Change in a Chinese Village 1949-1999. Stanford, CA: Stanford University Press.

Yoshino K (2000) The epistemic contract of bisexual erasure. Stanford Law Review 52: 353-461.

Zheng W, et al. (2011) Detraditionalisation and attitudes to sex outside marriage in China. Culture, Health \& Sexuality 13(5): 497-511.

Jingshu Zhu, a PhD candidate in Law and Anthropology at Leiden University in The Netherlands, is currently carrying out research for her interdisciplinary project 'Queer(ing) Marriage, Parenthood, and Elderly Care in Chinese Family Law'. Her research interests include critical feminist legal theories, queer theories, kinship studies and Chinese lesbian and gay studies. She has been actively participating in the les-bi-gay rights movements in China, while keeping a critical eye on the normalizing effects of the politics of inclusion. 